


\section{Sample for the Dutch FADN 2018}

J.L. Roskam, R.W. van der Meer and H.B. van der Veen

This study was carried out by Wageningen Economic Research and was commissioned and financed by the Dutch Ministry of Agriculture, Nature and Food Quality within the context of the Statutory Research Tasks

(WOT-06-001-006).

Wageningen Economic Research

Wageningen, July 2021

REPORT

2021-089

ISBN 978-94-6395-867-7 
Roskam, J.L., R.W. van der Meer and H.B. van der Veen, 2021. Sample for the Dutch FADN 2018. Wageningen, Wageningen Economic Research, Report 2021-089. 30 pp.; 2 fig.; 6 tab.; 18 ref.

Het Europese FADN (Farm Accountancy Data Network) is een instrument om het agrarische inkomen te monitoren en de invloed van het Europese landbouwbeleid te evalueren. De bedrijven die zijn opgenomen in het Nederlandse FADN vormen een steekproef van land- en tuinbouwbedrijven uit de Landbouwtelling. Dit rapport beschrijft de achtergronden van de steekproef en de ontwikkelingen aangaande de populatie en de steekproef in 2018. Alle stappen van het bepalen van het selectieplan, het werven van bedrijven en de kwaliteit van de steekproef worden beschreven.

The FADN (Farm Accountancy Data Network) is a European instrument for evaluating the income of agricultural holdings and the impacts of the Common Agricultural Policy. The farms included in the Dutch FADN are a sample of agricultural and horticultural companies from the Agricultural Census. This report explains the background of the sample and the developments concerning the population and sample of 2018. All phases - from the determination of the selection plan, the recruitment of farms to the quality control of the final sample - are described in this report.

Key words: FADN, sample, population, agriculture, horticulture

This report can be downloaded for free at https://doi.org/10.18174/549212 or at www.wur.eu/economic-research (under Wageningen Economic Research publications).

(C) 2021 Wageningen Economic Research

P.O. Box 29703, 2502 LS The Hague, The Netherlands, T +31 (0)70 33583 30,

E communications.ssg@wur.nl, http://www.wur.eu/economic-research. Wageningen Economic Research is part of Wageningen University \& Research.

\section{(cc) BY-NC}

This work is licensed under a Creative Commons Attribution-Non Commercial 4.0 International License.

(C) Wageningen Economic Research, part of Stichting Wageningen Research, 2021

The user may reproduce, distribute and share this work and make derivative works from it. Material by third parties which is used in the work and which are subject to intellectual property rights may not be used without prior permission from the relevant third party. The user must attribute the work by stating the name indicated by the author or licensor but may not do this in such a way as to create the impression that the author/licensor endorses the use of the work or the work of the user. The user may not use the work for commercial purposes.

Wageningen Economic Research accepts no liability for any damage resulting from the use of the results of this study or the application of the advice contained in it.

Wageningen Economic Research is ISO 9001:2015 certified.

Wageningen Economic Research Report 2021-089 | Project code 2282200607

Cover photo: Shutterstock 


\section{Contents}

$\begin{array}{ll}\text { Preface } & 5\end{array}$

$\begin{array}{ll}\text { Summary } & 6\end{array}$

$\begin{array}{ll}\text { Samenvatting } & 7\end{array}$

$\begin{array}{llr}1 & \text { Introduction } & 8\end{array}$

2 Population of the Dutch FADN $\quad 9$

$\begin{array}{lll}2.1 & \text { Introduction } & 9\end{array}$

2.2 Overview 9

$\begin{array}{lll}2.3 \text { Coverage } & 10\end{array}$

$3 \quad$ Selection plan $r$

3.1 Introduction $\quad 12$

3.2 Farm types $\quad 12$

3.3 Number of sample farms per farm type 13

$\begin{array}{lll}3.4 & \text { Stratification scheme } & 13\end{array}$

$\begin{array}{ll}\text { 3.5 Sample farms per stratum } & 14\end{array}$

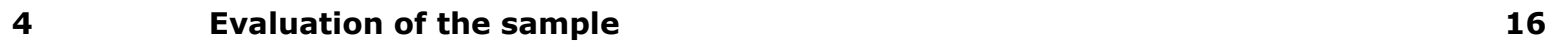

$\begin{array}{lll}4.1 & \text { Level of response } & 16\end{array}$

$\begin{array}{lll}4.2 & \text { Statistical reliability } & 17\end{array}$

$\begin{array}{lll}4.3 & \text { Comparison sample and target population } & 18\end{array}$

$5 \quad$ Conclusions $r$

$\begin{array}{ll}\text { References and websites } & \mathbf{2 0}\end{array}$

Appendix 1 Sampling Theory and Methodology 22

$\begin{array}{lll}\text { Appendix } 2 & \text { Design principles and requirements } & 25\end{array}$

Appendix 3 Number of farms per stratum in the target population 27

$\begin{array}{lll}\text { Appendix } 4 & \text { Sampling fractions } & 28\end{array}$

$\begin{array}{lll}\text { Appendix } 5 & \text { Response rate by type of farm } & 29\end{array}$ 



\section{Preface}

The Centre for Economic Information (in Dutch, Centrum voor Economische Informatievoorziening, CEI) is one of the programme units for Statutory Research Tasks and is concerned with the efficient and effective collection, processing, recording and management of databases and presentation of statistical data on various activities of players in the agricultural sector and rural areas in the Netherlands and abroad. One of the statutory research tasks is to yearly send data relating to a sample of 1,500 farms to the European Commission annually as its contribution to the European Farm Accountancy Data Network (FADN) This statutory research task is carried out by Wageningen Economic Research on behalf of CEI. This report describes all phases of the Dutch FADN sample for the accounting year 2018 - from the determination of the selection plan and the recruitment of farms to the quality control of the final sample.

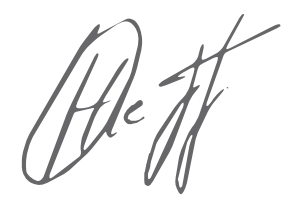

Ir. O. Hietbrink

Business Unit Manager Wageningen Economic Research Wageningen University \& Research

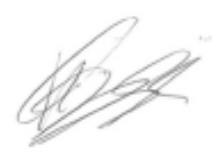

Dr. H.C.J. Vrolijk Head of the CEI Wageningen University \& Research 


\section{Summary}

The Farm Accountancy Data Network (FADN) is a European instrument for evaluating the income of agricultural holdings and the impacts of the Common Agricultural Policy. This report describes the sample of the Dutch FADN for the accounting year 2018 - from the determination of the selection plan and the recruitment of farms to the quality control of the final sample.

The farms included in the Dutch FADN are a sample of agricultural and horticultural holdings from the Dutch Agricultural Census. A selection plan is developed to make sure that the sample is a good representation of the different farming types and farm sizes in the Netherlands. In 2018, the statutory obligation of the European Commission for delivering data of at least 1,500 farms has been met. The Dutch Agricultural Census was used as the source for determining the sampling frame. Increasing numbers of agricultural and horticultural farms are missing in the Agricultural Census.

For the selection plan, the distribution of agricultural holdings across different farm types was made first. Within each farm type, the number of strata is minimised by using several statistical and practical criteria. A selection plan was initially made across strata defined by farm type and farm size to estimate the population mean of the farm size as accurately as possible. Thereafter, the plan was adjusted to reflect the heterogeneity of farms in other aspects such as species grown. Generally, greater heterogeneity of farms results in a larger number of sample farms. For the selection plan of 2018, it was investigated whether it makes sense to distinguish more organic farm types in the selection plan. However, it is concluded that the current farm types related to organic farming, included in the sample, are sufficient.

The response rate among companies that were approached to take part in the FADN is around $19 \%$. A low response rate combined with a declining number of farms in the population can lead to strata with fewer sample farms available than the optimum according to the selection plan. A lower response rate can result in a selection bias if non-responsive farms systematically differ from the recruited farms. Additional research has been performed to provide insight into the implications of the inclusion probabilities of companies in the Dutch FADN for the estimated population characteristics. Although the sample companies in the Dutch FADN have been carefully selected and recruited, their actual inclusion probabilities are difficult to determine. Some recommendations for future research are therefore to increase the response rate and document the reasons for non-response including: 1) limit biases in the selection and recruitment processes as much as possible, 2) pay more attention to poststratification weightings, and 3) gain insight into the possible selection bias due to non-response and warm acquisition through simulation studies and cross-validation with other data sources. 


\section{Samenvatting}

Het Farm Accountancy Data Network (FADN) is een Europees instrument voor de evaluatie van het inkomen van landbouwbedrijven en de effecten van het gemeenschappelijk landbouwbeleid. Dit rapport beschrijft de samenstelling van de steekproef van het Nederlandse FADN voor het boekjaar 2018 - van de vaststelling van het selectieplan, de werving van bedrijven tot de kwaliteitscontrole van de uiteindelijke steekproef.

De bedrijven die zijn opgenomen in het Nederlandse FADN zijn een steekproef van land- en tuinbouwbedrijven uit de Landbouwtelling. Er wordt een selectieplan opgesteld om te garanderen dat de steekproef een goede afspiegeling is van de verschillende bedrijfstypen en grootteklassen in Nederland. In 2018 is aan de wettelijke verplichting van de Europese Commissie voor het aanleveren van minimaal 1.500 bedrijven voldaan. De Nederlandse Landbouwtelling is gebruikt als de bron voor het vaststellen van het steekproefkader. Een toenemend aantal bedrijven zijn niet opgenomen in de Landbouwtelling.

Voor het steekproefplan wordt eerst een verdeling van bedrijven over bedrijfstypen gemaakt. Binnen het type wordt het aantal strata geminimaliseerd met behulp van een aantal statistische en praktische randvoorwaarden. Het steekproefplan wordt gemaakt op basis van strata van bedrijfstype en bedrijfsomvang om het populatiegemiddelde van de bedrijfsomvang zo nauwkeurig mogelijk te schatten. Het plan werd daarna nog aangepast om rekening te houden met de heterogeniteit van de bedrijven op andere gebieden zoals type gewassen. In het algemeen geldt hoe heterogener de bedrijven zijn, hoe groter het aantal steekproefbedrijven. Ten behoeve van het selectieplan 2018 is onderzocht of het zinvol is om in het selectieplan meer biologische bedrijfstypen te onderscheiden. De conclusie is dat de huidige bedrijfstypen die verband houden met biologische landbouw, opgenomen in de steekproef, voldoende zijn.

De respons van bedrijven die worden benaderd om deel te nemen aan het FADN is ongeveer $19 \%$. De respons daalt langzaam. Een lage respons gecombineerd met een afnemend aantal bedrijven in de populatie kan resulteren in strata met minder beschikbare steekproefbedrijven dan het optimum volgens het selectieplan. Een lagere respons kan resulteren in een vertekening wanneer nietreagerende bedrijven systematisch verschillen van de gerekruteerde bedrijven. Er is aanvullend onderzoek gedaan om inzicht te geven in de implicaties van de insluitingskansen van bedrijven in de Nederlandse FADN voor de geschatte populatiekenmerken. Hoewel de steekproefbedrijven in de Nederlandse FADN zorgvuldig zijn getrokken en gerekruteerd, is hun werkelijke insluitingskans moeilijk te bepalen. Hieruit volgend komen een aantal aanbevelingen voor toekomstig onderzoek om de respons te verhogen en om de redenen voor non-respons te vinden waaronder: 1) bias in de selectie en rekruteringsprocessen zoveel mogelijk te beperken en goed te documenteren, 2) meer aandacht te besteden aan post-stratificatie wegingen, en 3) inzicht verwerven in de mogelijke selectiebias door non-respons en warme acquisitie door simulatiestudies en kruisvalidatie met andere databronnen. 


\section{Introduction}

The Farm Accountancy Data Network (FADN) is a European instrument for evaluating the income of agricultural holdings and the impacts of the Common Agricultural Policy. On a yearly basis financial, economic, physical and structural data from farms are collected, with the aim of monitoring the income and business activities of EU agricultural holdings and to evaluate the impact of the Common Agricultural Policy. ${ }^{1}$ In the Netherlands, the data are collected by Wageningen Economic Research on behalf of the Centre for Economic Information (in Dutch: Centrum voor Economische Informatievoorziening, CEI). The Netherlands are required to provide information of at least 1,500 farms to the European Commission as its contribution to the FADN. In addition to the number of farmers, there are other requirements as well, e.g. the EC has requirements on the sampling process and the quality of the sample. Therefore, this report provides a justification for the establishment of the selection plan of the Dutch FADN for accounting year 2018 and evaluates the quality of the sample.

This report first describes the relationship between the population and the target population in Chapter 2. Based on the target population, a selection plan is made. The selection plan is presented in Chapter 3 and describes for which farm types and SO classes, farms have to be recruited. Chapter 4 describes the recruitment of farms for the FADN and the evaluation of the quality of the sample. In addition, there is an appendix with background information. Appendix 1 provides an overview of the methodology of sampling used for the FADN. In Appendix 2, the design principles of the FADN are described. Appendices 3-5 comprise more detailed background information tables.

1 https://ec.europa.eu/agriculture/fadn_en 


\section{Population of the Dutch FADN}

\section{$2.1 \quad$ Introduction}

All agricultural companies together form the agricultural population. For the Dutch FADN, the Agricultural Census is used to select farms for FADN. Section 2.2 explains the background of the Agricultural Census and section 2.3 describes the quality of this Census.

\subsection{Overview}

Based on the trade register of the Chamber of Commerce, companies are approached for the Agricultural Census, where additional information on the agricultural activities is collected to describe the structure of the Dutch agricultural sector (data on farms, livestock, crops and special topics).Theoretically, all agricultural companies in the Netherlands are registered in this trade register. The Agricultural Census is the data source upon which the sample is based. Ideally, the Agricultural Census includes all Dutch farms with more than $€ 3,000$ of total Standard Output (SO). ${ }^{2}$ The total SO is used to determine the economic size of a farm. The Standard Output per product is the average monetary value of the agricultural output at farm-gate price, in euro per hectare or per head of livestock (Eurostat, 2019).

Not all the farms in the population are represented in the sample (see Figure 2.1). The figure consists of different layers. The outer layer represents all existing farms. Based on FADN regulations, the target population is defined as the farms with more than $€ 25,000$ of total SO.

The Agricultural Census is the most comprehensive list of farms and is used to select farms for FADN. For this purpose, farms above $€ 25,000 \mathrm{SO}$ are included in the sampling frame. The number of farms included in this sampling frame can differ from the number in the target population due to nonresponse in the agricultural census and errors in the specification of the farm.

When recruiting a farm, two additional criteria are applied (see Appendix 1 and 2). These criteria are a share of income from primary activities ( $>25 \%$ in total income) and a share of agricultural turnover ( $50 \%$ in total turnover). However, this implies that only after approaching the farms it can be determined whether the farms meet the criteria or not, since the defined criteria cannot be applied to the Agricultural Census.

\footnotetext{
2 The sum of all the SOs per hectare of crops and per head of livestock in a farm is a measure of its overall economic size,
} expressed in euros. 


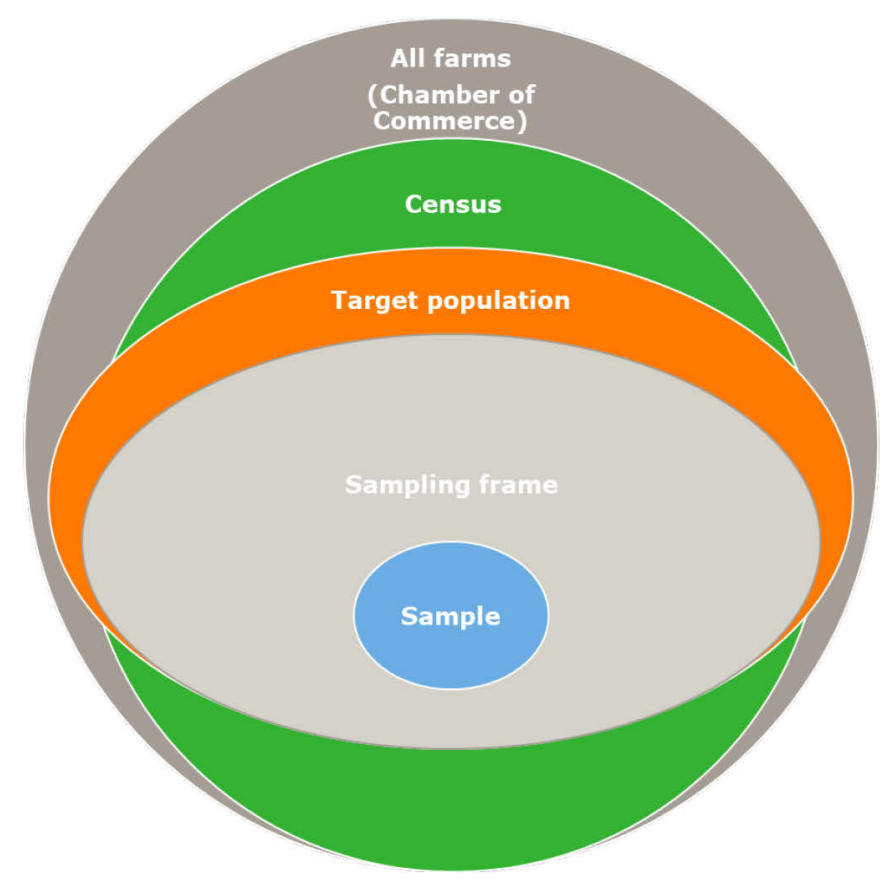

Figure 2.1 Relationship between target population, sampling frame and sample

\subsection{Coverage}

For the Dutch FADN, a minimum economic size of $€ 25,000$ SO has been applied for the definition of the target population. In 2018, this lower threshold meant that almost 9,000 farms of the census were not part of the target population of FADN. Although this is a large number of farms, they only account for less than $0.5 \%$ of the total production capacity expressed in SO (see Table 2.1). This is different compared to 2010; in this year 19,993 farms of the census were not part of the target population of FADN, which was $1.1 \%$ of the total production capacity expressed in SO (van der Veen et al., 2012).

Table 2.1 Number of farms and their relative economic importance (measured in total SO) in the 2018 Agricultural Census compared to the target population

\begin{tabular}{lrrr} 
& Number of farms & Percentage of farms (\%) & Percentage of So (\%) \\
All farms in the Agricultural Census (a) & 53,906 & 100 & 100 \\
\hline Farms with less than $€ 25,000$ SO (b) & 8,871 & 16.46 & 0.49 \\
\hline Farms above minimum threshold (a) - (b) & 45,035 & 83.54 & 99.51 \\
\hline
\end{tabular}

Source: Agricultural Census, Statistics Netherlands, calculations by Wageningen Economic Research.

\section{Quality of the sampling frame}

Although the Agricultural Census is intended to include all Dutch farms, this is not the case in practice. There are several possible explanations for this. On the one hand, not all farms receive an invitation to participate in the Agricultural Census, for instance because the business is registered with the Chamber of Commerce as a trading company rather than as a farming company. On the other hand, there are farms that do not respond to the request, despite it being obligatory. Table 2.2 illustrates the number of farms participating in the FADN sample (see Chapter 3 ) but missing from the Agricultural Census. An increasing number of sample farms included in the FADN are not included in the Agricultural Census, mainly horticulture under glass. In recent years, actions have been taken to improve the quality of the Agricultural Census for these sectors and the results will be followed up. 
Table 2.2 Number of FADN sample farms not included in the Agricultural Census

\begin{tabular}{|c|c|}
\hline Accounting year & Number of farms missing \\
\hline 2014 & 6 \\
\hline 2015 & 38 \\
\hline 2016 & 53 \\
\hline 2017 & 67 \\
\hline 2018 & 73 \\
\hline
\end{tabular}




\section{Selection plan}

\subsection{Introduction}

A selection plan is a key document which specifies how the selection activities are organised, initiated and conducted conform the regulations of the EU including requirements on the sampling process and the quality of the sample. ${ }^{3}$ The determination of the selection plan for the Dutch FADN consists of the following steps:

1. Determination of the farm types (Section 3.2)

2. Determination of the number of farms per farm type (Section 3.3)

3. Determination of the stratification scheme, depending on the number of farms per farm type in the target population (Section 3.4)

4. Distribution of sample farms per farm type over the size classes (Section 3.4)

\subsection{Farm types}

Dutch FADN farm types differ in some cases from the European FADN (see European classification of farms). Some farm types are not present in Dutch agriculture (e.g. olives, citrus fruit) and some types are further detailed because they are of substantial importance for Dutch agriculture in terms of economic size or because of their relevance for policy makers (such as starch potatoes). For a number of farming types - dairy farms and field crops - a distinction is made between organic farming and non-organic farming (see Vrolijk and Lodder, 2002). The latter consists of organic field crop farms, field vegetables farms and combined crop farms. For the selection plan of 2018, it was investigated whether it makes sense to distinguish more biological farm types in the selection plan. In the 2017 selection plan, only organic crops and organic dairy cattle were identified as separate types. To be distinguished as a separate farm type in the selection plan, the farm type must, on the one hand, be policy-relevant, whereas, on the other hand, the type must contain sufficient companies in the population so that a sample of sufficient size can be drawn. To be able to make statements about an individual type, we apply a lower limit of 30 sample companies. This means that the population must contain a minimum of around 200-300 companies.

For the 2018 sampling plan, it was investigated for which sectors it could be relevant to distinguish the biological type. Both the number of organic pig and poultry farms and the share in production (measured in standard yield) are increasing, in poultry farming to a greater extent than in pig farming. Yet the number of companies in the individual sectors is too low to recruit enough sample companies. An option could be to merge the poultry farms and the pig farms into organic livestock farms. However, researchers have indicated that a combined group of organic livestock farms is not interesting. In pig farming, the organic sector is very limited in size and in poultry farming it is expected that the various concepts and labels will become a more important distinguishing factor than organic. However, differences in concepts and labels cannot be taken into account in the sampling plan since the focus is on farm types and not on concepts and labels. In goat farming, a relatively large part of the production volume is organic. Organic goat farming has not grown since 2010 . The absolute number of organic goat farms is also too limited to distinguish them as a separate group in the sampling plan.

In addition, State Secretary Van Dam indicated in his letter to the House of Representatives (21 November 2016) that specific policies for organic farming are no longer necessary. Organic agriculture is, however, seen as a sector with a 'pioneering role in the field of sustainable production methods such as soil-improving methods in which the ecosystem is leading'. Most of the area under

\footnotetext{
3 Further information regarding the sample selection can be found on the following website:
} https://ec.europa.eu/agriculture/rica/methodology2_en.cfm. 
organic agriculture consists of arable/open field vegetables and fodder crops and grassland (approximately 85\% in 2016 according to the Statistics Netherlands Agricultural Census). The monitoring of the pioneering role is possible because organic arable farming/vegetable farms and organic dairy farming are both represented as separate groups in the Wageningen Economic Research sample. It was therefore decided to recommend not to add additional organic groups to the sampling plan.

\subsection{Number of sample farms per farm type}

When determining the number of sample farms per type of farm, important considerations are the number of farms in the target population, the economic significance of a type of farm, the amount of land used, and the heterogeneity within a type (the dispersion in size measured in SO) and or variety of crops within a farm type. The selection plan largely matches the numbers of farms that would be expected based on the criteria of economic importance, heterogeneity and number. The distribution differs, depending on which criteria are applied. Hence, the selected distribution is a compromise. The total number of farms in one farming type should be at least 30. A lower number of farms would make it very difficult to perform useful analyses on such farm types (Vrolijk and Lodder, 2002). The number of FADN sample farms per farm type in 2018 did not change compared to 2017.

\subsection{Stratification scheme}

EU Regulation 2015/220 specifies the size classes and puts restrictions on the clustering of size classes. Based on the SO, the variance of strata, given different clustering schemes, is calculated and used to determine the optimum clustering scheme (Appendix 1) per farm type. Size classes for the strata vary between the types of farming. This is because the size distribution of farms differs greatly between farm types (Ge et al., 2017). For example, field crop farms are in general much smaller in terms of SO than greenhouse horticulture farms. For the 2018 selection plan, there has been a change in the optimum clustering scheme. In previous years, the goat farms were part of the 'other grazing livestock farms' type and were therefore stratified in the same way as the 'other grazing livestock farms'. The average size of goat farms is however significantly larger than the other grazing livestock farms, partly due to an increase in the NSO standard for dairy goats (see also Section 4), which means that a different stratification is optimal. In addition, the number of companies in the small strata continues to decline, so that the number of sample companies is no longer feasible. In 2018, therefore, the smallest strata will be merged and the largest stratum split up. Table 3.1 shows the optimum clustering scheme for each type of farming for the 2018 target population. 
Table 3.1 Clustering scheme 2018 (size classes in a single colour in one row represent one stratum)

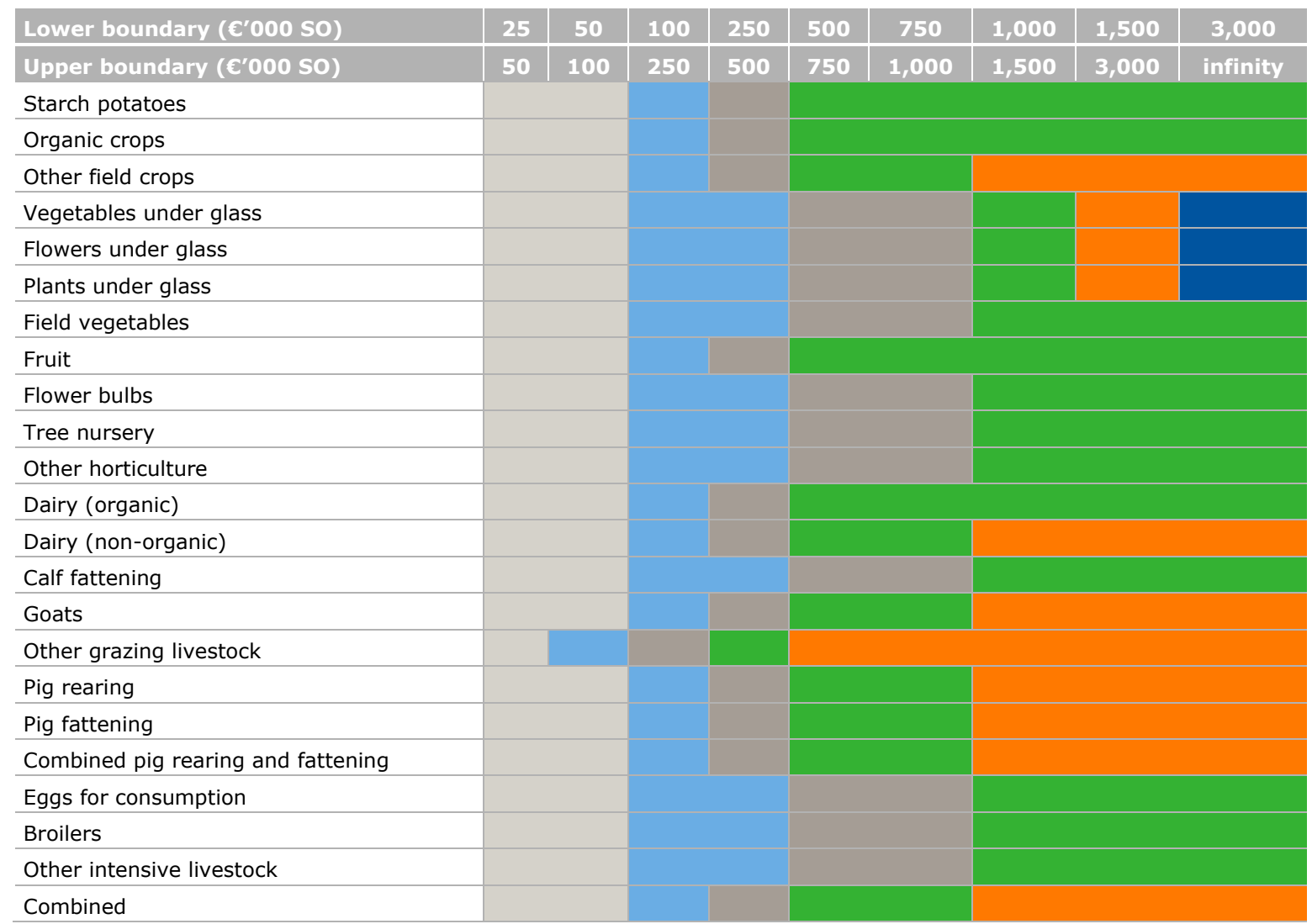

\subsection{Sample farms per stratum}

Table 3.2 presents the optimum selection plan for 2018, based on the design principles described in Appendix 2. The distribution of the sample farms across the size classes has remained broadly the same and is mainly determined by the further increase in the scale of farming activities. However, in some cases, the absolute number of farms in the population in the largest stratum has decreased (according to the agricultural census), implying less sample farms within the stratum. This applies for example to other horticulture farms. 
Table 3.2 Selection plan per stratum 2018

\begin{tabular}{|c|c|c|c|c|c|c|c|c|c|c|}
\hline Lower threshold ( $C^{\prime} 000$ SO) & 25 & 50 & 100 & 250 & 500 & 750 & 1,000 & 1,500 & 3,000 & \multirow{2}{*}{ Total } \\
\hline Upper threshold ( $\left.\mathrm{C}^{\prime} 000 \mathrm{SO}\right)$ & 50 & 100 & 250 & 500 & 750 & 1,000 & 1,500 & 3,000 & infinity & \\
\hline \multicolumn{11}{|l|}{ Type of farm } \\
\hline \multicolumn{11}{|l|}{ Field crop farms } \\
\hline - Starch potatoes & & 4 & 9 & 10 & \multicolumn{5}{|c|}{7} & 30 \\
\hline - Organic crops & & 5 & 9 & 11 & \multicolumn{5}{|c|}{5} & 30 \\
\hline - Other field crops & & 25 & 37 & 33 & & 41 & \multicolumn{3}{|c|}{14} & 150 \\
\hline \multicolumn{11}{|l|}{ Horticulture } \\
\hline Vegetables under glass & & 2 & \multicolumn{2}{|c|}{27} & & 25 & 17 & 33 & 26 & 130 \\
\hline Plants under glass & & 2 & \multicolumn{2}{|c|}{11} & \multicolumn{2}{|r|}{6} & 10 & 15 & 21 & 65 \\
\hline Flowers under glass & & 4 & \multicolumn{2}{|c|}{26} & \multicolumn{2}{|c|}{29} & 20 & 23 & 16 & 118 \\
\hline Field vegetables & & 5 & \multicolumn{2}{|c|}{27} & & 11 & \multicolumn{3}{|c|}{12} & 55 \\
\hline Fruit & & 2 & 6 & 13 & \multicolumn{5}{|c|}{17} & 38 \\
\hline Tree nursery & & 2 & \multicolumn{2}{|c|}{30} & & 21 & \multicolumn{3}{|c|}{17} & 70 \\
\hline Flower bulbs & & 2 & \multicolumn{2}{|c|}{9} & & 11 & \multicolumn{3}{|c|}{15} & 37 \\
\hline Other horticulture & & 2 & \multicolumn{2}{|c|}{5} & & 12 & \multicolumn{3}{|c|}{26} & 45 \\
\hline
\end{tabular}

Grazing livestock

Dairy

\begin{tabular}{|c|c|c|c|c|c|c|c|}
\hline Dairy (organic) & & & 6 & 15 & \multicolumn{2}{|c|}{8} & 30 \\
\hline Dairy (non-organic) & & & 26 & 120 & 106 & 44 & 300 \\
\hline Calf fattening & & & \multicolumn{2}{|c|}{9} & 12 & 17 & 40 \\
\hline Goats & & & 6 & 11 & 8 & 3 & 30 \\
\hline Other grazing livestock & 6 & 12 & 3 & 4 & \multicolumn{2}{|c|}{8} & 33 \\
\hline
\end{tabular}

Intensive livestock

\begin{tabular}{|c|c|c|c|c|c|c|}
\hline Pig rearing & 1 & 2 & 11 & 13 & 21 & 48 \\
\hline Pig fattening & 1 & 7 & 6 & 5 & 29 & 48 \\
\hline Combined pig rearing and fattening & 1 & 1 & 3 & 7 & 26 & 38 \\
\hline Broilers & 1 & \multicolumn{2}{|c|}{4} & 6 & 19 & 30 \\
\hline Other intensive livestock & 1 & \multicolumn{2}{|c|}{4} & 9 & 16 & 30 \\
\hline
\end{tabular}

The sampling plan is primarily based on the method of Neyman Allocation (Neyman, 1934). This allocation is adjusted to take the heterogeneity of the farms in other aspects into account. For example: crops are not a stratification variable, but to be able to take the great heterogeneity of crops grown on tree nurseries and field vegetable farms into account, the number of sample farms has been increased.

A sampling fraction is the ratio of the size of the sample to that of the population (Cochran, 1977). The sampling fractions differ between strata. This is a result of the disproportionate sampling technique used for the FADN sample. The sampling fraction also gives an indication of the number of farms available for recruitment in a stratum. In strata with a high sampling fraction, only a limited number of farms are available for recruitment. Appendix 3 shows the number of farms per stratum in the target population while Appendix 4 presents an overview of the sampling fractions (number of farms in the sample compared to the number of farms in the target population). 


\section{Evaluation of the sample}

The evaluation of the sample is based on three criteria: level of response, statistical reliability and representativeness. These criteria are discussed in separate paragraphs in this chapter.

\subsection{Level of response}

Sample farms are retained as much as possible (see Vrolijk and Cotteleer, 2005). Nevertheless, new farms must be recruited every year to compensate for the farms that are lost, due to structural changes in farms or because of changes in the selection plan. It also happens that farms stop or no longer want to participate, and therefore new farms have to be recruited. To meet the required number of farms for delivery to the European Commission, a successful recruitment process is important.

The Agricultural Census is used to select farms that meet the criteria for inclusion in the sample. Addresses for the selected farms are requested from the Ministry of Agriculture, Nature and Food Quality. The farms are then approached to ask if they would be interested in taking part in the Farm Accountancy Data Network. More than 400 farms were approached for the sample for 2018. Some of these farms $(10 \%)$ were unsuitable for inclusion in the sample, for example because the entrepreneur stopped the farm operations or will stop soon, or the farm forms part of a larger company without the possibility of making a distinction between the accountancy data of the farm and other parts of the concern. Ultimately, 72 farms were recruited. As can be seen from Figure 4.1, the response rate (number of recruited farms/(number of farms approached - unsuitable farms) *100) has been between $15 \%$ and $25 \%$ for several years. The low response rate in recent years is related to the fact that recruitment primarily takes place in sectors with below-average response rates (see Appendix 5). A response rate of $19 \%$ in 2018 is not exceptionally low compared to preceding years. A low response rate combined with a declining number of farms in the population can lead to strata with fewer sample farms available than the optimum according to the selection plan. Another problem is that a low response rate can lead to a selection bias if non-responsive farms systematically differ from the recruited farms (see Appendix 1).

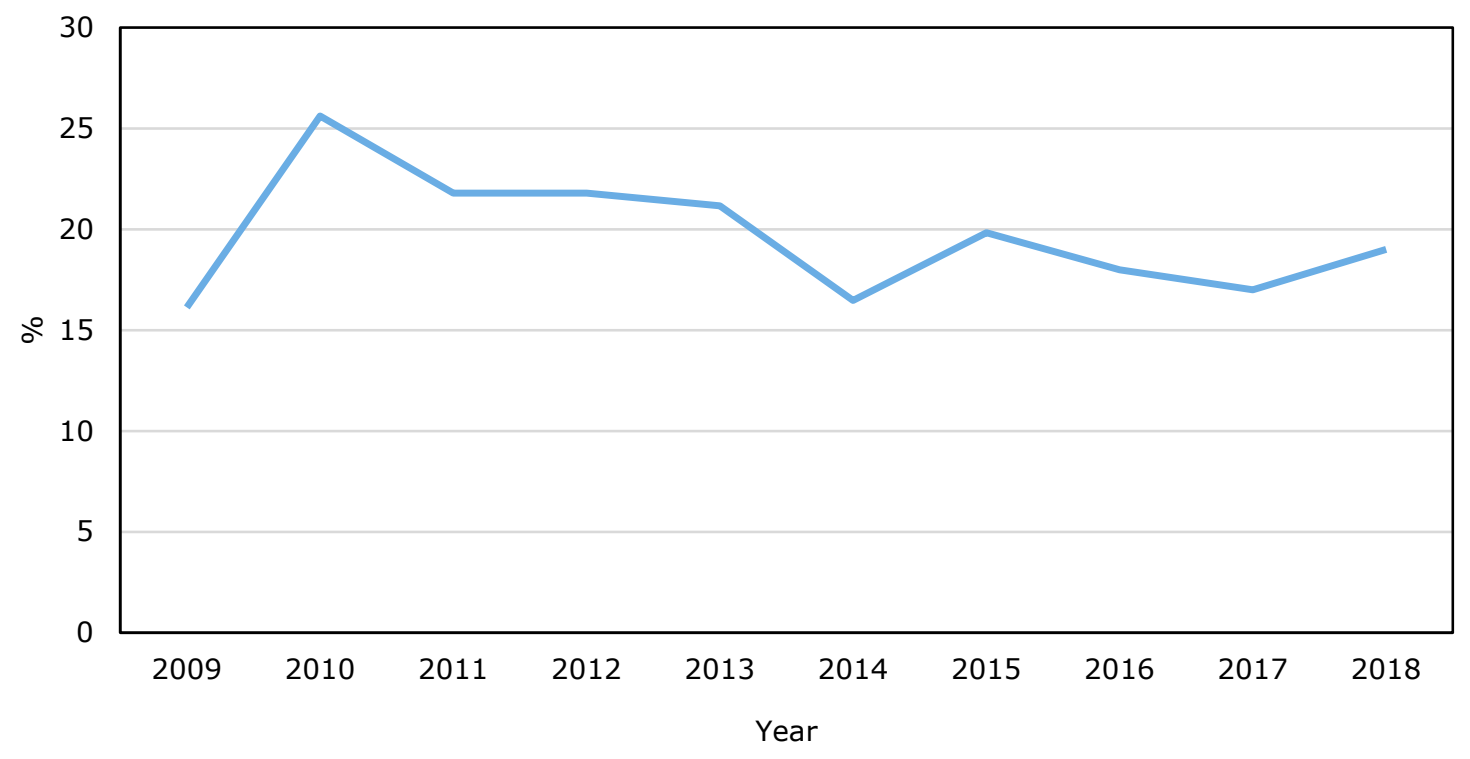

Figure 4.1 Response rates, 2009-2018 
To investigate opportunities to increase the response rate as well as to investigate (potential) reasons for non-response, additional research has been carried out by van Wassenaer (2019). The main reasons for this research were previous studies on the application of alternative weightings for FADN companies, the renewal of the sampling plan (Ge and van der Veen, 2018) and the questions from data collectors of Wageningen Economic Research regarding warm acquisition (i.e. approaching known companies). The previous studies showed the importance to examine the nature and extent of possible non-response errors. In addition, attention should be paid to the difference between the actual inclusion probabilities and the assumed containment probabilities. The aim of the research of van Wassenaer (2019) was to provide insight into the implications of the incorrect or unknown inclusion probabilities of companies in the Dutch FADN for the estimated population characteristics. Based on literature study and Monte-Carlo simulations, the consequences and possible solutions were explored and recommendations were made for the choice of farms and further research. Although the sample companies in the Dutch FADN have been carefully drawn and recruited, their actual inclusion probabilities are difficult to determine. To ensure the continued validity of the Dutch FADN as a representative sample it is it is important to:

- Avoid biases in the recruitment process as much as possible.

- Pay more attention to post-stratification weightings.

- Gain insight into the possible selection bias due to non-response and warm acquisition through simulation studies and cross-validation with other data sources.

These recommendations will be further investigated in future research in order to increase the response rate as well as for finding reasons for non-response.

\subsection{Statistical reliability}

Reliability is about the consistency of a measure. The reliability of estimates can be measured using the standard error of the estimate of a variable to calculate the confidence interval. This confidence interval describes the range of the true population value, given a certain level of certainty. The $95 \%$ confidence interval (with a critical t-value of 1.96) ranges from the calculated average minus 1.96 times the standard error to the calculated average plus 1.96 times the standard error. For example, the standard error of 7,120 for field crop farms signals that the average farm income on such farms can vary within the confidence interval; average +/- $1.96 * 7,120$ (Table 4.1). A higher relative standard error (see Appendix 1) implies less reliable estimates, but the value is greatly affected by the absolute value of the average. If the average value approaches zero, the relative standard error can become very large.

Table 4.1 Reliability of estimates: standard error and relative standard error (in italics) of important goal variables per main type of farm, based on CSP a) variant (2018)

\begin{tabular}{|c|c|c|c|c|}
\hline \multirow[t]{2}{*}{ Type of farming } & \multicolumn{4}{|c|}{ Goal variable } \\
\hline & Farm income, $c$ & Total revenues, $\mathbf{c}$ & Profitability a) & Total income, $\mathrm{c}$ \\
\hline \multirow[t]{2}{*}{ Field crops } & 7,120 & 16,174 & 2.18 & 7,426 \\
\hline & 0.08 & 0.04 & 0.02 & 0.07 \\
\hline \multirow[t]{2}{*}{ Vegetables under glass } & 35,031 & 281,038 & 1.76 & 35,300 \\
\hline & 0.10 & 0.11 & 0.02 & 0.10 \\
\hline \multirow[t]{2}{*}{ Cut flowers under glass } & 32,800 & 165,557 & 2.67 & 32,713 \\
\hline & 0.17 & 0.09 & 0.03 & 0.17 \\
\hline \multirow[t]{2}{*}{ Pigs } & 10,208 & 40,452 & 0.94 & 10,731 \\
\hline & 1.09 & 0.04 & 0.01 & 0.43 \\
\hline \multirow[t]{2}{*}{ Poultry } & 17,462 & 61,437 & 1.75 & 17,530 \\
\hline & 0.15 & 0.06 & 0.02 & 0.13 \\
\hline \multirow[t]{2}{*}{ Grazing livestock } & 3,452 & 8,455 & 0.97 & 3,675 \\
\hline & 0.08 & 0.02 & 0.01 & 0.07 \\
\hline \multirow[t]{2}{*}{ All farms } & 3,446 & 15,330 & 0.8 & 3,516 \\
\hline & 0.04 & 0.03 & 0.01 & 0.04 \\
\hline
\end{tabular}

a) Corporate Social Performance (CSP) is the variant of data collection in which a wide range of data is collected for EU and national policies. It covers all the topics that are today considered relevant in a report on the sustainability of a farm. About $80 \%$ of the farms included in the sample are in the CSP variant; b) Revenues per $€ 100$ in costs. 
There are clear differences in the reliability of estimates between different types of farms. The estimates for grazing livestock are among the most reliable estimates (the lowest standard error). This is due to the relatively large number of farms included in the sample, which reflects the importance of the dairy sector in Dutch agriculture, as well as because of the homogeneity of Dutch dairy farms. The field crop farms have a low standard error as well. The European Commission has no requirements regarding the reliability. However, it is one of the factors that is considered when determining the distribution of farms over both the farm types and size classes.

\subsection{Comparison sample and target population}

The representativeness (interpreted as the absence of systematic differences between the sample and the target population, Van der Veen et al., 2014, see also Appendix 1) of certain specialist types of farms are shown in Table 4.2. For none of the main farm types, there is a significant difference in the acreage per farm and the SO per farm between the sample and the target population. Compared to 2017, no significant difference is found for the dairy farms. Adjustments in the stratification helped to avoid a statistical difference for 2018.

Table 4.2 Comparison of farms in the target population and farms in the sample

\begin{tabular}{|c|c|c|c|c|c|c|}
\hline & $\begin{array}{l}\text { So/farm } \\
\text { population }\end{array}$ & $\begin{array}{l}\text { So/farm } \\
\text { sample }\end{array}$ & $\begin{array}{c}\text { Significant } \\
(5 \%)\end{array}$ & $\begin{array}{l}\text { Ha/farm } \\
\text { population }\end{array}$ & $\begin{array}{l}\text { Ha/farm } \\
\text { sample }\end{array}$ & $\begin{array}{c}\text { Significant } \\
(5 \%)\end{array}$ \\
\hline Arable farms & 226,275 & 242,767 & NS a) & 57.0 & 62.0 & NS \\
\hline Horticulture open air & 505,634 & 598,027 & NS & 19.6 & 21.6 & NS \\
\hline Dairy farms & 422,296 & 434,274 & NS & 55.1 & 56.6 & NS \\
\hline Pig farms & 942,295 & 892,953 & NS & - & - & NA \\
\hline
\end{tabular}

a) NS = non-significant; b) NA = not applicable.

The sampling plan is based on farm types (e.g. open-air vegetable growers) and not on the underlying crops or animals present on the farm (e.g. cauliflower). This can result in certain crops or animals being underrepresented or overrepresented in the sample, particularly for types that are less common. To obtain an impression of the extent to which this is the case, a comparison was made between the weighted totals in euros of SO for the crops and animals in the sample against the totals from the Agricultural Census. Although the analysis has shown that differences for the other categories do arise, they are in general not significant because of a large dispersion. 


\section{$5 \quad$ Conclusions}

This report describes the sample of the Dutch FADN for the accounting year 2018 - from the determination of the selection plan and the recruitment of farms to the quality control of the final sample. Within the report a justification for the selection plan for the Dutch FADN was provided. The report describes how farms in the sample are distributed according to farm type and size class in such a way that that the sample is a good representation of the different farming types and farm sizes in the Netherlands. In addition, the quality of the sample is analysed. Although the sample farms in the Dutch FADN have been carefully drawn and recruited, their actual inclusion probabilities are difficult to determine. A couple of recommendations are therefore identified for future research in order to be able to maintain the quality of the sample in the future. These recommendations for future research include the increase of the response rate and to document reasons for non-response to learn from that. 


\section{References and websites}

Australian Bureau of Statistics (2017). What is a Standard Error and Relative Standard Error, Reliability of estimates for Labour Force data:

https://www.abs.gov.au/websitedbs/d3310114.nsf/Home/What+is+a+Standard+Error+and+Relat ive+Standard+Error, +Reliability+of+estimates+for+Labour+Force+data

Bethlehem, J. (2008). Wegen als correctie voor non-respons. Centraal Bureau voor de Statistiek (CBS). Statistische methoden (08005), Voorburg/Heerlen, Nederland.

Cochran, W.G. (1977). Sampling Techniques. New York: John Wiley \& Sons.

Eurostat (2019). Statistics explained: https://ec.europa.eu/eurostat/statisticsexplained/index.php/Glossary:Standard_output_(SO).

Everitt, B. S. (2003). The Cambridge Dictionary of Statistics. CUP. ISBN 978-0-521-81099-9.

FADN: http://ec.europa.eu/agriculture/rica/.

Ge, L., R.W. van der Meer, H.B. van der Veen and H.C.J. Vrolijk (2017). Design principles and quality of the sample of agricultural and horticultural holdings. Report 2017-016 Wageningen Economic Research 2017.

Ge, L., and H.B. van der Veen (2018). 'Notitie vernieuwing van het steekproefplan voor het BedrijvenInformatienet 2016' (Dutch). Internal Note Wageningen Economic Research.

Kruskal, W. and F. Mosteller (1979a). Representative sampling, I: Nonscientific literature. International Statistical Review, 47, 13-24.

Kruskal, W. and F. Mosteller (1979b). Representative sampling, II: Scientific literature, excluding statistics. International Statistical Review, 47, 113-127.

Kruskal, W. and F. Mosteller (1979c). Representative sampling, III: the current statistical literature. International Statistical Review, 47, 245-265.

Kruskal, W. and F. Mosteller (1980). Representative sampling, IV: the history of the concept in statistics, 1895 - 1939. International Statistical Review, 48, 169-195.

Neyman, J. (1934). On the two different aspects of the representative method: The method of stratified sampling and the method of purposive selection. Jour. Roy. Stat. Soc., 97, 558-606.

Van Wassenaer, L. (2019). 'Insluitingskansen van BIN-bedrijven?' (Dutch). Internal Note Wageningen Economic Research.

Veen, H.B. van der, I. Bezlepkina, P. de Hek, R. van der Meer and H.C.J. Vrolijk (2012). Sample of Dutch FADN 2009-2010. Design principles and quality of agricultural and horticultural holdings. LEI-report 2012-061 November 2012, LEI Wageningen UR, The Hague.

Veen, H.B. van der, L. Ge, R. van der Meer and H.C.J. Vrolijk (2014). Sample of Dutch FADN 2012. Design principles and quality of agricultural and horticultural holdings. LEI-report 2014-027 December 2014, LEI Wageningen UR, The Hague. 
Vrolijk, H.C.J. and K. Lodder (2002). Voorstel tot vernieuwing van het steekproefplan voor het Bedrijven-Informatienet. Report 1.02.02. LEI, The Hague, 2002.

Vrolijk, H.C.J. and G. Cotteleer (2005). Non-respons en rotatie in het Bedrijven-Informatienet. Kwantitatieve en kwalitatieve analyse van de effecten. Report 1.05.01 LEI, The Hague, 2005. 


\section{Appendix 1 Sampling Theory and Methodology}

\section{Concepts and Methods}

\section{Population}

According to Cochran (1977), the definition of the population is: 'The aggregate from which the sample is chosen.' A population is thus an aggregate of creatures, things, cases, etc.

\section{Target population}

Cochran (1977) defined the target population as the population about which information is desired. The population to be sampled (the sampled population) should coincide with the target population.

\section{Sampling frame}

The sampling frame is the source material or device from which a sample is drawn. It is a list of all those within a population who can be sampled, and may include individuals, households or institutions.

\section{Sampling}

Sampling is a statistical procedure that relates to the selection of the individual sampling units. Sampling helps to make statistical inferences about the population.

\section{Sample}

In statistics, a sample refers to a set of observations drawn from a population. A sample is a subset of a population. A sample can be collected either at random or through systematic methods.

\section{Sampling method used for FADN disproportionate stratified sampling}

Sampling units from the population that meet certain criteria form the target population. Estimates are made for the target population based on these sample farms. This might raise the question of how conclusions can be drawn for the target population if only a limited number of farms are observed. The answer to this question can be found in sampling techniques such as stratified random sampling (Cochran, 1977). Sampling units that are included in the sample must be representative for the whole target population (no systematic differences between the sample and the population, Van der Veen et al., 2014).

An important issue is how to ensure that the sampling units are representative for the whole target population. This can be achieved through a disproportionate stratified random sample. A stratified sample implies that the target population is divided into several groups (strata). Subsequently, the sampling units are randomly selected from each of the groups. The variables that define these groups must be chosen in such a way that the sampling units within any one group are similar (at least in terms of the important aspects). Sampling from each group ensures that the sample includes sampling units from all groups consistently with different characteristics. Stratification ensures that all groups are properly represented, thereby allowing separate estimates for all groups. All groups combined make up the whole target population. This method of sampling allows unbiased estimates to be made for the whole target population of farms.

Disproportionate means that not all farms have the same chance of being included in the sample. Groups that are relatively homogeneous, i.e. containing farms that show a high degree of similarity, will have a lower chance of being included in the sample. In cases of less homogeneous groups, it is important to have a larger number of observations if reliable estimates are to be made. 


\section{Random sampling}

Random selection is an application of probability sampling in which each unit in the population has an equal chance of being included in the sample (Cochran, 1977). In the case of stratified sampling, each unit in a stratum has the same chance of being included.

\section{Neyman allocation}

Optimum allocation refers to a method of sample allocation based on stratified sampling. This allocation is sometimes called Neyman allocation, after Neyman (1934). The purpose of Neyman allocation is to maximise survey precision given a fixed sample size. According to Neyman allocation, the 'best' sample size for stratum $h$ would be:

$$
n_{h}=\mathrm{n} \frac{N_{h} \sigma_{h}}{\sum_{i=1}^{L} N_{i} \sigma_{i}}
$$

where $n_{h}$ is the sample size for stratum $h, \mathrm{n}$ is the total sample size, $\mathrm{N}_{\mathrm{h}}$ is the population size for stratum $h, \sigma_{h}$ is the standard deviation of stratum $h$ and $L$ represents the number of strata. The denominator (i.e. $\sum_{i=1}^{L} N_{i} \sigma_{i}$ ) corresponds to the sum of the population size times the standard deviation of all strata.

\section{Quality of survey samples}

\section{Accuracy}

The degree to which a measurement represents the true value of something. The confidence interval indicates the accuracy of a measure. The smaller the confidence interval of a measure, the higher the accuracy of a measure.

\section{Reliability}

The overall consistency of a measure, i.e. how dependably an observation is exactly the same when repeated. The stand error can be an indication of the degree of reliability.

\section{Representativeness}

Representativeness is a well-known concept in the context of sampling. Nevertheless, depending on the context, there are different definitions and interpretations. Kruskal and Mosteller (1979a, 1979b, 1979c, and 1980) distinguish the following interpretations (among others):

1. Random without a selective mechanism.

2. The sample as a miniature representation of the target population: all subpopulations in the sample are in the same proportions as in the total population.

3. No significant difference between the estimated value of the target value and the actual value of the target population (compare Van der Veen et al., 2014).

4. Inclusion in the sample of certain farm types or farms in certain size classes.

An indication of the representativeness for a random sample without selection (interpretation 1 ) is the $\mathrm{R}$ indicator. This indicator gives an indication of the possible non-response bias (Bethlehem et al., 2008). To be able to calculate the R-indicator, the response chance of a farm is estimated based on several variables available in the Agricultural Census (Appendix 2).

Interpretation 2 is intuitively the most logical and the most used interpretation in survey research. It is of less importance for the FADN because the FADN is a disproportionate stratified sample. To be able to determine whether a sample is representative according to interpretations 3 and 4, it is necessary to indicate which characteristic should be well represented by the sample. This is the target variable for research. Talking about representativeness in broad terms is therefore not very meaningful.

\section{Non-response}

Not all farms approached for participation in the FADN are willing to participate, leading to a nonresponse in the recruitment process. Non-response is the failure to measure some of the units in the selected sample (Cochran, 1977). A low response rate does not necessarily provide incorrect results 
(Bethlehem, 2008). However, if the non-response is biased, certain groups can be overrepresented or underrepresented.

\section{Standard error}

The standard error of a statistic is the standard deviation of the sampling distribution of that statistic. Standard errors are important because they reflect how much sampling fluctuation a statistic will show (Everitt, 2003). In statistics, a sample mean deviates from the actual mean of a population - this deviation is the standard error of the mean.

\section{Relative Standard Error}

The relative standard error is the standard error expressed as a fraction of the estimate and is usually shown as a percentage. Estimates with a Relative Standard Error of $25 \%$ or greater are subject to high sampling error and should be used with caution (Australian Bureau of Statistics, 2017). 


\section{Appendix 2 Design principles and requirements}

\section{EU regulations}

EU Regulation 2015/220 sets out rules for the target population, such as definitions for farming types and size classes. The regulation prescribes several size classes and options for the clustering of size classes, the threshold ( $€ 25,000$ SO for the Netherlands) and the minimum number of sample farms for every EU country (1,500 for the Netherlands).

\section{Target population}

The EU Regulation describes that, for the Dutch FADN, a minimum economic size of $€ 25,000$ SO should be applied to the target population. This minimum was introduced after the introduction of the SO in 2010 and it was required to fit in with the existing EU size classes. Moreover, the coverage of the sample should not become worse (Van der Veen et al., 2012). The minimum economic size exists to be able to select the commercial farms only, which is required by the European Commission.

\section{Sampling frame}

For practical and methodological reasons, a limitation on 'other income of the farm' is used for sample farms. A farm should gain at least $25 \%$ of its turnover from primary agricultural activities.

Furthermore, agricultural activities (in the broadest sense including other gainful activities) should comprise the largest share of the turnover of the farm.

\section{Number of sample farms per farm type}

When determining the number of sample farms per type of farm, the number of farms in the target population, the economic significance of a type of farm, the amount of land used, and the heterogeneity within a type (the dispersion in size measured in SO) are important considerations. If the amount of land used were adopted strictly as the criterion, the sample would consist largely of arable and dairy farms. Farm types can be heterogeneous in terms of scale (measured as the SO) or crops. The selection plan largely matches the numbers of farms that would be expected based on the criteria of economic importance, heterogeneity and number. Hence, the selection plan is a compromise between different approaches. A few observations are presented below:

- The number of arable and dairy cattle farms is greater than would be expected based on heterogeneity. This is because these sectors are particularly relevant for policy and because of the number of farms in these sectors.

- There are fewer mixed farms and other grazing livestock farms. These sectors are less important for research and policy, but they are important for reporting several characteristics of the total target population.

- More horticultural companies have been included than would be expected given the number of such farms in the target population. This is primarily due to the wide variation in crops that are cultivated, particularly at tree nurseries and flower bulb farms.

- For most open-field types, there are relatively more farms in the sampling plan than would be optimum given the numbers of companies. This is due to the greater heterogeneity in crops grown on horticultural farms. This also applies to greenhouse horticulture; in addition, these businesses are highly relevant to policy in terms of energy issues in particular. 
The total number of farms in one farming type should be at least 30. A lower number of farms would make it very difficult to perform useful analyses on such farm types (Vrolijk and Lodder, 2002).

\section{Stratification scheme and sample farms per stratum}

The FADN sample distinguishes groups based on economic size and type of farming. Within a type of farm, the principles of optimum allocation (see Appendix 1) determine both the stratification scheme and the distribution of farms over the size classes. The variance of strata in different clustering schemes (as described in the EU Regulation) is calculated based on the SO. The optimum clustering scheme is chosen based on the standard error. As the number of strata increases, the variance and the standard error of the target variable will gradually decrease. If the reduction in the variance of adding an extra stratum is less than $5 \%$, no more strata are added. For more details, see Vrolijk and Lodder (2002). Given this optimised stratification scheme, more sample farms are assigned to a stratum in the event that farms are shown to be more heterogeneous. In the extreme example that all farms were exactly alike, one observation is sufficient to make reliable estimates.

Besides the abovementioned statistical criteria, the maximum number of farms within a stratum is $10 \%$ of the total number of farms of the target population within that stratum. A larger number would lead to problems in recruiting farms.

\section{Weighting system}

The purpose of the weighting system is to take account of different sampling fractions for different strata. In the production of FADN results, weighted averages are calculated using these weightings applied to each individual farm recorded in the sample. The individual weighting is equal to the ratio between the numbers of farms of the same classification stratum (type of farming $x$ economic size class) in the population and in the sample. The farms in the target population within a stratum are continually changing. These changes could influence the inclusion probability of farms in one particular stratum at the time of recruitment. In theory, these differences in inclusion probabilities should be considered in the estimation process in order to ensure unbiased estimators. This would lead to a very complicated system with many different substrata with different inclusion probabilities. This procedure is not applied in the FADN. The theoretical assumption of a strictly random sample cannot be validated. However, given the circumstances the current method is justifiable.

\section{Recruitment}

Farms are randomly selected from the Agricultural Census based on the selection plan. Farmers from a selected farm are approached and asked whether they would be willing to participate. If the farmer declines, another farm from the same strata will be approached. 


\section{Appendix 3 Number of farms per stratum in the target population}

Table A3.1 Number of farms per stratum (target population) in 2018

\begin{tabular}{|c|c|c|c|c|c|c|c|c|c|}
\hline Lower threshold ( $\varepsilon^{\prime} 000$ SO) & 25 & 50 & 100 & 250 & 500 & 1,000 & 1,500 & 3,000 & \multirow{2}{*}{ Total } \\
\hline Upper threshold ( $\left.\mathrm{C}^{\prime} 000 \mathrm{SO}\right)$ & 50 & 100 & 250 & 500 & 1,000 & 1,500 & 3,000 & infinity & \\
\hline \multicolumn{10}{|l|}{ Type of farm } \\
\hline \multicolumn{10}{|l|}{ Field crop farms } \\
\hline - Starch potatoes & \multicolumn{2}{|c|}{213} & 302 & 173 & \multicolumn{4}{|c|}{71} & 759 \\
\hline - Organic crops & \multicolumn{2}{|c|}{109} & 126 & 77 & \multicolumn{4}{|c|}{55} & 367 \\
\hline - Other field crops & \multicolumn{2}{|c|}{2,759} & 2,010 & 1,121 & 550 & \multicolumn{3}{|c|}{150} & 6,590 \\
\hline \multicolumn{10}{|l|}{ Horticulture } \\
\hline Vegetables under glass & \multicolumn{2}{|c|}{45} & \multicolumn{2}{|c|}{174} & 151 & 108 & 185 & 160 & 823 \\
\hline Flowers under glass & \multicolumn{2}{|c|}{41} & \multicolumn{2}{|c|}{283} & 169 & 74 & 142 & 113 & 822 \\
\hline Plants under glass & \multicolumn{2}{|c|}{21} & \multicolumn{2}{|c|}{108} & 95 & 56 & 121 & 180 & 581 \\
\hline Field vegetables & \multicolumn{2}{|c|}{204} & \multicolumn{2}{|c|}{379} & 101 & \multicolumn{3}{|c|}{98} & 782 \\
\hline Fruit & \multicolumn{2}{|c|}{282} & 400 & 428 & \multicolumn{4}{|c|}{224} & 1,334 \\
\hline Tree nursery & \multicolumn{2}{|c|}{474} & \multicolumn{2}{|c|}{753} & 198 & \multicolumn{3}{|c|}{155} & 1,580 \\
\hline Flower bulbs & \multicolumn{2}{|c|}{75} & \multicolumn{2}{|c|}{250} & 113 & \multicolumn{3}{|c|}{157} & 595 \\
\hline Other horticulture & \multicolumn{2}{|c|}{259} & & & 211 & & 260 & & 1,327 \\
\hline Grazing livestock & & & & & & & & & \\
\hline Dairy (organic) & & & 128 & 249 & & & 1 & & 474 \\
\hline Dairy (non-organic) & & & 2,954 & 7,708 & 3,440 & & 491 & & 14,955 \\
\hline Calf fattening & & & & & 408 & & 270 & & 1,207 \\
\hline Goats & 16 & 15 & 44 & 91 & & & 26 & & 392 \\
\hline Other grazing livestock & 2,547 & 1,660 & 705 & 156 & & & 8 & & 5,146 \\
\hline Intensive livestock & & & & & & & & & \\
\hline Pig rearing & & & 49 & 151 & 261 & & 263 & & 737 \\
\hline Pig fattening & & & 371 & 308 & 313 & & 324 & & 1,487 \\
\hline Combined pig rearing and fattening & & & 24 & 70 & 190 & & 348 & & 640 \\
\hline Eggs for consumption & & & & & 171 & & 231 & & 629 \\
\hline Broilers & & & & & 103 & & 239 & & 412 \\
\hline Other intensive livestock & & & & & 182 & & 220 & & 542 \\
\hline Other & & & & & & & & & \\
\hline Combined & & & 649 & 574 & 556 & & 280 & & 2,854 \\
\hline Total & & & & & & & & & 45,035 \\
\hline
\end{tabular}

Source: Agricultural Census, Statistics Netherlands, calculations by Wageningen Economic Research. 


\section{Appendix 4 Sampling fractions}

The sample is a disproportionate stratified sample. The term 'disproportionate' means that the chances of being included can vary between the strata. The chance of being included is calculated as the number of sample farms divided by the total number of farms in the target population. Table A4.1 shows that the sampling fractions are higher for greenhouse horticulture companies than they are for other sectors. Sampling fractions are higher in certain strata because the heterogeneity of farms in a particular stratum are high.

Table A4.1 Sampling fraction according to the 2018 Agricultural Census by stratum

\begin{tabular}{|c|c|c|c|c|c|c|c|c|}
\hline Lower threshold ( $\mathrm{C}^{\prime} 000 \mathrm{SO}$ ) & \multicolumn{2}{|r|}{25} & \multirow{2}{*}{$\frac{50}{250}$} & \multirow{2}{*}{$\begin{array}{l}100 \\
500\end{array}$} & \multirow{2}{*}{$\frac{250}{1,000}$} & \multirow{2}{*}{$\frac{500}{1,500}$} & \multirow{2}{*}{\begin{tabular}{|l|}
1,000 \\
3,000
\end{tabular}} & \multirow{2}{*}{$\begin{array}{r}1,500 \\
\text { infinity }\end{array}$} \\
\hline upper threshold ( $\varepsilon^{\prime} 000$ SO) & 50 & 100 & & & & & & \\
\hline \multicolumn{9}{|l|}{ Type of farm } \\
\hline \multicolumn{9}{|l|}{ Field crops } \\
\hline - Starch potatoes & & 0.02 & 0.03 & 0.06 & \multicolumn{4}{|c|}{0.10} \\
\hline - Organic crops & & 0.05 & 0.07 & 0.14 & \multicolumn{4}{|c|}{0.09} \\
\hline - Other field crops & & 0.01 & 0.02 & 0.03 & 0.07 & \multicolumn{3}{|c|}{0.09} \\
\hline \multicolumn{9}{|l|}{ Horticulture } \\
\hline Vegetables under glass & & 0.04 & \multicolumn{2}{|c|}{0.16} & 0.17 & 0.16 & 0.18 & 0.16 \\
\hline Plants under glass & & 0.10 & \multicolumn{2}{|c|}{0.10} & 0.06 & 0.18 & 0.12 & 0.12 \\
\hline Flowers under glass & & 0.10 & \multicolumn{2}{|c|}{0.09} & 0.17 & 0.27 & 0.16 & 0.14 \\
\hline Field vegetables & & 0.02 & \multicolumn{2}{|c|}{0.07} & 0.11 & \multicolumn{3}{|c|}{0.12} \\
\hline Fruit & & 0.01 & 0.02 & 0.03 & \multicolumn{4}{|c|}{0.08} \\
\hline Tree nursery & & 0.00 & \multicolumn{2}{|c|}{0.04} & 0.11 & \multicolumn{3}{|c|}{0.11} \\
\hline Flower bulbs & & 0.03 & \multicolumn{2}{|c|}{0.04} & 0.10 & \multicolumn{3}{|c|}{0.10} \\
\hline Other horticulture & & 0.01 & \multicolumn{2}{|c|}{0.01} & 0.06 & \multicolumn{3}{|c|}{0.10} \\
\hline \multicolumn{9}{|l|}{ Grazing livestock } \\
\hline \multicolumn{9}{|l|}{ Dairy } \\
\hline - Organic & & 0.17 & 0.05 & 0.06 & \multicolumn{4}{|c|}{0.09} \\
\hline - Non-organic & & 0.01 & 0.01 & 0.02 & 0.03 & \multicolumn{3}{|c|}{0.09} \\
\hline Calf fattening & & 0.03 & & & 0.03 & & & \\
\hline Goats & 0.13 & 0.40 & 0.30 & 0.09 & & & 0.01 & \\
\hline Other grazing livestock & 0.00 & 0.01 & 0.00 & 0.03 & & & 0.10 & \\
\hline Intensive livestock & & & & & & & & \\
\hline Pig rearing & & 0.08 & 0.04 & 0.07 & 0.05 & & & \\
\hline Pig fattening & & 0.01 & 0.02 & 0.02 & 0.02 & & & \\
\hline Combined pig rearing and fattening & & 0.13 & 0.04 & 0.04 & 0.04 & & & \\
\hline Eggs for consumption & & 0.13 & & & 0.04 & & & \\
\hline Broilers & & 0.33 & & & 0.06 & & & \\
\hline Other intensive livestock & & 0.14 & & & 0.05 & & & \\
\hline Other & & & & & & & & \\
\hline Combined & & 0.01 & 0.01 & 0.02 & 0.06 & & & \\
\hline
\end{tabular}




\section{Appendix 5 Response rate by type of farm}

Table A5.1 Response rate in different types of farm, recruitment for CSP variant, 2018

\begin{tabular}{llll} 
Farming types a) & Total farms & Unsuitable farms (\%) & Response rate $(\%)$ \\
Field crops & & & 13 \\
\hline - Starch potatoes & 21 & 29 & 33 \\
\hline - Organic crops & 11 & 18 & 25 \\
\hline - Other field crops & 63 & 13 & \\
\hline Horticulture & & & \\
\hline Vegetables under glass & 3 & 0 & 14 \\
\hline - Sweet pepper & 30 & 3 & 23 \\
\hline - Tomato & 120 & 9 & 21 \\
\hline Flowers under glass & 42 & 7 & 5 \\
\hline Plants under glass & 42 & 7 & 67 \\
\hline Field vegetables & & & 13 \\
\hline Intensive livestock & 3 & 0 & 29 \\
\hline Pig rearing & 43 & 12 & 20 \\
\hline Pig fattening & 25 & 4 & \\
\hline Combined pig rearing and fattening & 403 & 10 & \\
\hline Total & &
\end{tabular}

a) Only farm types with recruiting activities are displayed. 
Wageningen Economic Research P.O. Box 29703

2502 LS The Hague

The Netherlands

$\mathrm{T}+31(0) 703358330$

E communications.ssg@wur.nl

www.wur.eu/economic-research

Wageningen Economic Research REPORT

2021-089
The mission of Wageningen University \& Research is "To explore the potential of nature to improve the quality of life". Under the banner Wageningen University \& Research, Wageningen University and the specialised research institutes of the Wageningen Research Foundation have joined forces in contributing to finding solutions to important questions in the domain of healthy food and living environment. With its roughly 30 branches, $6,800$ employees ( $6,000 \mathrm{fte})$ and 12,900 students, Wageningen University \& Research is one of the leading organisations in its domain. The unique Wageningen approach lies in its integrated approach to issues and the collaboration between different disciplines. 



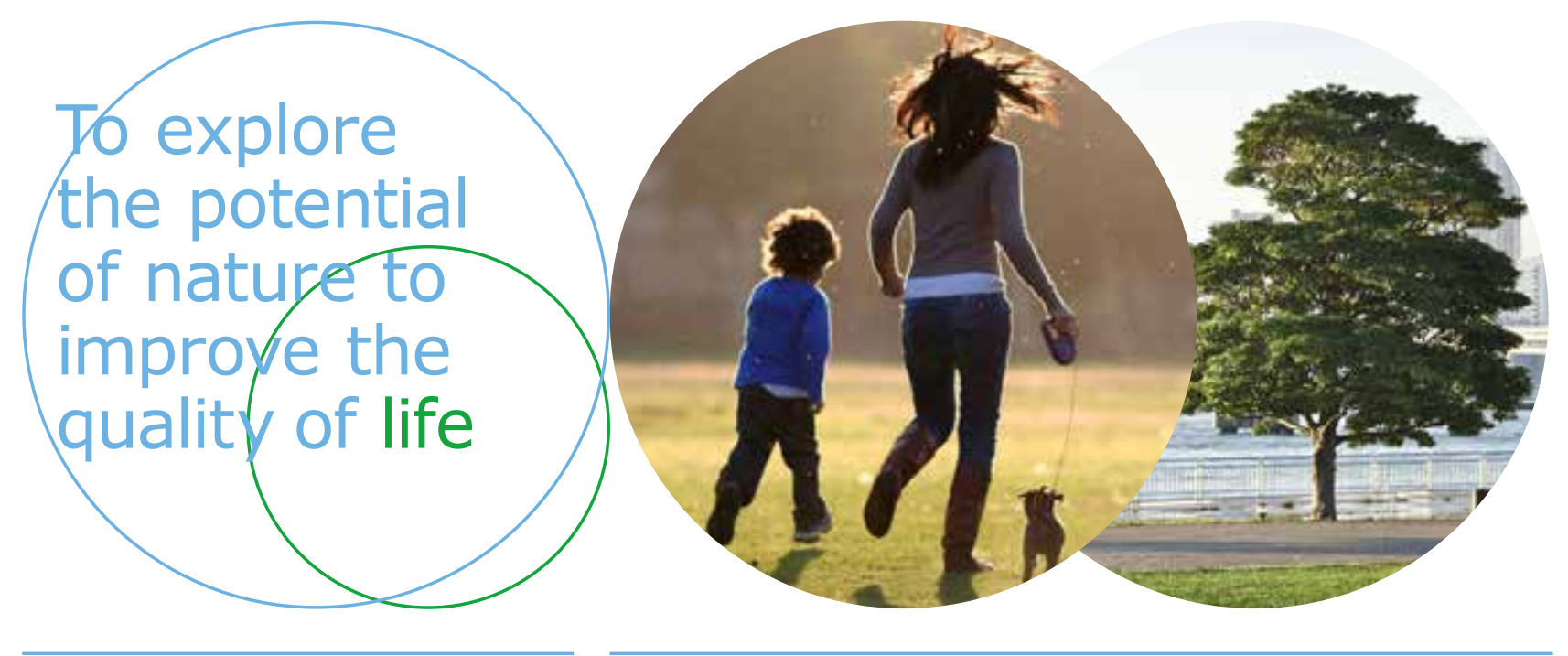

Wageningen Economic Research P.O. Box 29703

2502 LS Den Haag

The Netherlands

$\mathrm{T}+31(0) 703358330$

E communications.ssg@wur.nl

www.wur.eu/economic-research

Report 2021-089

ISBN 978-94-6395-867-7
The mission of Wageningen University \& Research is "To explore the potential of nature to improve the quality of life". Under the banner Wageningen University \& Research, Wageningen University and the specialised research institutes of the Wageningen Research Foundation have joined forces in contributing to finding solutions to important questions in the domain of healthy food and living environment. With its roughly 30 branches, 6,800 employees $(6,000 \mathrm{fte})$ and 12,900 students, Wageningen University \& Research is one of the leading organisations in its domain. The unique Wageningen approach lies in its integrated approach to issues and the collaboration between different disciplines. 